\title{
CIVILISED COMMUNITIES
}

Reconsidering the 'Gloomy Tale' of Immigration and Social Order in a Changing Town

\begin{abstract}
Immigration and its effects on crime, social disorder and community tensions remains a pervasive feature of public, government and academic discourse. This discourse often considers immigration, and immigrants themselves, as a threat to the community's existing moral and social order. This paper presents the findings of a case study that used quantitative and qualitative methods to explore the experiences of social order following a recent wave of Polish migration in a small working class town in the North West of England. The key findings show that the assumed association of migration with a disruption to social order receives little support. Rather, the social order in the studied locale is predominantly managed and maintained through 'civilised relationships' between migrants and established residents, thus failing to culminate into conflict between the two groups. This situation of 'civility' provides an alternative to the preponderance of previous research telling a 'gloomy tale' of immigration and its impact on local communities.
\end{abstract}

Keywords: Polish Immigration, Strangers, Civilised Communities, Conflict, Social (Dis)Order

\section{Introduction}

Debates surrounding immigration and its effects on crime, social disorder and community tensions (whether actual or perceived) have been a pervasive feature of public, government, and academic discourse for many years, and remain important to this day (Hughes, 2007). Concern over segregation, conflict and the 'parallel lives' that diverse cultures lead has indeed been high on the political agenda ever since the 2001 riots in the Northern towns of Oldham, Bradford and Burnley, where various government policies have focused on trying to encourage greater 'community cohesion' (Griffiths, 2013). Recent waves of migration to the UK from Central and Eastern Europe have once again stimulated this debate on immigration and its imagined 'threat' to social order. In May 2004, the European Union opened its doors to eight new accession countries that were granted full access to the UK labour market. Although it is difficult 
to determine the exact numbers of migrants who moved to the UK during and after this time (see Office for National Statistics et al, 2011 for a discussion of migration data limitations), what is clear is that substantial and rapid changes have been witnessed in local neighbourhoods throughout the country, and this contemporary migration is arguably "one of the most important social phenomena in recent years" (Pollard et al, 2008: 54). The limited data that is available on such migration flows demonstrate that of these new migrants, the overwhelming majority have migrated from Poland (Home Office et al, 2006; Stenning et al, 2006; Burrell, 2009).

Although Poland has a long established history of migration, some commentators have deemed this a 'new migration' due predominantly to its size and rapidity, with many suggesting it is the largest wave of migration in British history (Stenning et al, 2006: 9; The Economist, 2008; Burrell, 2009). An important feature of this so-called 'new migration' (Stenning et al, 2006: 9) therefore was its geographical dispersal with many small towns and more rural areas experiencing international migration for the first time. As Stenning et al (2006: 10) emphasise however, "[n]otwithstanding this changing geography, the vast majority of research, empirical and anecdotal material relates to new migrants in London, the east and south east. As a result, far less is known about A8 migrants in more northern and western regions." This paper seeks to address this by presenting the findings of a case study carried out in Crewe, a small working class town in the North West of England that witnessed an unexpected and unprecedented inmigration of Polish migrant workers and their families.

The initial media response to this migration was, both locally and nationally, rather negative with these new migrant groups being associated with rising crime, disorder and fear: 'has Eastern European immigration fuelled a crime wave in Britain?' (Campbell, 2012); 'mass immigration to blame for knife culture, Chief Constable warns' (Slack, 2008); 'Britons have "greater fear” of immigration' (Sinclair, 2011). While some have suggested that this 'new' migration has "gone some way to decoupling the issue of immigration from that of race" (The Economist, 2008: 33), the perceived association of 'immigrants', 'strangers' or 'outsiders' with a disruption to social order remains a prevalent research issue (Elias and Scotson, 1965). There is a plethora of research on the negative attitudes of majority or 'established' populations towards the 'immigrant' 
or the 'stranger' (Hughes, 2007); yet there remains little criminological research on the lived experiences and subjectivities of new migrant communities themselves (Phillips and Bowling, 2003). The contribution of this paper therefore is to provide one of the few empirical and in-depth case studies that explores how both 'established' residents and new migrants perceive, adapt and negotiate their social relationships with each other in their day to day lives. Adding to the body of literature that tells a 'gloomy tale' of immigration, this paper aims to instead show that tension and conflict is not inevitable in all contexts. Using findings from a mixed methods case study in Crewe, the paper demonstrates how positive and civil social interaction can occur in communities undergoing rapid social change through immigration. Although claims of representativeness cannot be made here, the results are in line with a tentative but growing body of academic research.

The paper begins by providing a review of the academic literature on this gloomy tale. It then moves on to describe both the geographical and migration context in which the current study takes place, along with the research methods it incorporated. The paper ends by presenting the quantitative and qualitative findings that show the nuances of social relationships and suggest the assumed association of immigration with a disruption to social order receives little support in the current context. Instead, 'civilised relationships' between the two groups exist as the norm in this neighbourhood.

\section{The 'Gloomy Tale' of Immigration and Social Order}

The 'stranger', the 'immigrant', the 'alienated other', are themes that have preoccupied sociologists for many years (Simmel, [1908] 1971; Bauman, 1997; Young, 1999) and remain important to this day. Much of this research has linked the increased presence of strangers in an area to negative public perceptions of crime, 'incivility', and the moral indignation of others' public behaviour, resulting in disintegrated and strained intercommunity relations (Lupton and Tulloch, 1999 cited in Farrall et al, 2009: 107). According to Bauman (1997: 17), strangers are people who "do not fit the cognitive, moral and/or aesthetic map of the world ... whose sheer presence causes anxiety, obscurity and confusion, as they transcend and eclipse boundary lines." The 'ambient fear' (Bauman, 1997: 22) that is experienced, due to the permanent presence of 
strangers in neighbourhoods, obstructs collective efforts and a sense of solidity. In sociological terms, the perceived problem of the stranger, therefore, is their closeness in physical contact, but distance in social contact (Simmel, [1908] 1971; Wirth, 1938: 14).

Dating back to the Chicago School studies from the 1920s onwards, immigration has predominantly been found to disrupt bonds of 'kinship', 'neighbourliness' and 'sentiments' (Wirth, 1938: 11) that ultimately weaken social solidarity and disintegrate the social and moral order leading to competition for resources, crime and conflict (Thomas and Znaniecki, [1918-1920] 1996; McKenzie, [1924] 1971; Park et al, 1925; Burgess, 1925; North, [1926] 1971; Wirth, 1938).

Robert Putnam (2007) has famously contributed to this debate in more recent years with his 'hunkering down' thesis. Here he makes rather dystopian claims of a ubiquitous cynical society whereby individuals initially 'hunker down' as a direct consequence of immigration and increased diversity. Putnam (2007) contends that such diversity and mass immigration can, in the short-term at least, have detrimental effects on trust, social cohesion and the production of social capital for all groups within communities, resulting in altruistic behaviours and the overall moral fabric of communities to be in decline. Putnam's (2007) latest 'hunkering down' thesis is therefore considered a contemporary account of the classic idea of 'community lost', whereby immigration and diversity are seen as being the modern day sources of transience, segmentation and impersonality that disrupt social interaction in local neighbourhoods (Sampson, 2012).

Such tension and strained social relations can stem from communities' wider sensibilities regarding social change. In Stoke-on-Trent for example, just 15 miles away from Crewe, Gadd et al (2005) found that local residents often associate concerns with community deterioration and decline, and increasing crime and disorder, with 'immigrants'. In the working class town studied, those most socially marginalised or disadvantaged were found to attribute the perceived decline and social problems in their community with an increasing mass of 'foreigners' or 'immigrants' taking over 'their' neighbourhood. The authors found that feelings of powerlessness and status insecurity were shared by both the perpetrators of 'hate crime', as well as the wider white working class community, which allowed for a scapegoat to be formed in the all- 
encompassing image of the 'foreigner'. This resonates with the 'social threat' hypothesis, whereby immigrants or strangers are perceived as a 'realistic' and 'symbolic' threat. The former argues that established groups perceive a threat to the already strained economic and social resources in disadvantaged neighbourhoods experiencing immigration (Bobo, 1983; Herreros and Criado, 2009; Meuleman et al, 2009). This perceived threat to resources can take either an individual-level (based on self-interest) or group-level (based on societal-interest) form, leading to conflict and competition for resources (McLaren and Johnson, 2007). Such perceptions of threat can also be 'symbolic' in nature. In their seminal study The Established and The Outsiders, Elias and Scotson (1965: 147) show how newcomers act as a 'symbolic' threat to the established social and moral order of the neighbourhood. For these authors, established neighbourhood inhabitants are besieged by their status anxieties of class and respectability, and newcomers are perceived negatively as a threat to such status aspirations with the potential to lower their community down the status hierarchy. Established residents were thus found by Elias and Scotson (1965: 149) to exhibit particularly low levels of tolerance towards the social conduct of the newcomers and to engage in any activity that set themselves apart from these 'outsiders' to "confirm their own superiority in morals and manners, symbols of their own respectability, of their claim to a higher social status, of the existing social order." Elias and Scotson (1965: 153) called this a process of forming 'civilising differentials' between the established groups' perceived 'superior' civility as compared to the newcomers' 'inferior' civility. The unavoidable interdependence between established and newcomer groups as a result of migration thus culminated into tension and conflict between the groups in Elias and Scotson's study.

These collection of studies therefore predominantly tell a gloomy tale of immigration and its perceived social order consequences, whereby immigrants are often cast as 'outsiders' in their new neighbourhoods and as representatives of 'uncivil' behaviour. This, it is argued, ultimately results in tension, conflict and animosity between these diverse groups in contemporary changing neighbourhoods.

There is some tentative, but ever growing, body of literature across various disciplines and in a variety of social contexts that counter this assumed gloomy tale however. A 
recent article in The Guardian for example reports on a study that shows living in diverse areas makes individuals more, not less, tolerant (Bunting, 2014). The authors of the study suggest that simply observing diverse individuals interacting positively with each other has the potential to 'rub off' on others. They term this 'passive tolerance' and liken it to passive smoking, whereby individuals in diverse communities cannot avoid being influenced by positive social interaction just like those who are surrounded by smokers cannot avoid passively taking in smoke (Christ et al, 2014). Such findings are in line with Allport's (1958) contact theory that proposes prejudice and intolerance are reduced the more individuals come into contact with members of different ethnic and cultural groups. Earle and Phillips (2009: 128) similarly highlight the potential of 'multicultural conviviality' albeit in a very different social setting. The authors were concerned with exploring concepts of 'local liveability' and how the "daily negotiation of ethnic difference" is managed in a prison environment (Amin, 2002 cited in Phillips, 2008: 316). The authors found that social interaction between prisoners was much more complex and nuanced than previously assumed. Although prisoners at times suggested they felt more at ease with those from their own ethnic group based on feelings of commonality, they did express tolerant views whereby difference was considered rather unremarkable. Contact with those from different ethnic backgrounds was again found to encourage empathy with others and a convivial environment could be maintained.

The current paper aims to add to this body of literature by exploring the nuanced sensibilities and social relationships that exist amongst groups after a period of mass migration. In line with Elias and Scotson (1965: 167), who advocate a 'configurational' study of communities, this paper departs from existing research that has typically focused solely on the established community by recognising the 'interdependencies' of groups living within the same neighbourhood. The paper therefore aims to explore how both 'established' and 'migrant' groups perceive, adapt and negotiate their social relationships with each other, illustrating how 'civility' rather than conflict can exist. To do this, the paper reports on quantitative and qualitative data collected in a small town that experienced an unexpected and rapid 'shock' migration of Polish workers and their families. 


\section{The Setting}

The historical and social context of a locale has important implications for the social relationships that exist within it; that is, in the criminological study of social change and social order, the distinctiveness of 'place' matters (Bottoms, 2009: 50). The current research took place in Crewe, a small working class town in the North West of England that is surrounded by wealthy Cheshire countryside. Crewe is famously characterised by its industrial past and in particular as a railway town 'par excellence' (McKenna, 1908 cited in Drummond, 1995: 1). The legacy of these earlier industrial eras still live on to this very day, and Crewe's reputation as a 'workingman's town' (Drummond, 1995: 133) remains, with one author likening the area to "a soiled mechanic working hard in the middle of a grassy lawn" (Christiansen, 1993: 9). In 2001, Crewe had a population of just over 100,000 residents and over 45,000 households. Overall, Crewe could be characterised as a fairly typical homogeneous working class town with the majority of its residents being born in the UK (UK Census, 2001). These 2001 statistics do little to describe the situation in Crewe at the time of the research however, where the preoccupation of local inhabitants, local institutions, and the local and national media, was on the rapidly changing population with the increasing presence of Polish migrants.

According to Worker Registration Scheme (WRS) data obtained from the Home Office UK Border Agency, between May 2004 and June 2008, over 4,000 A8 migrants applied to work in the Crewe area. Of this number, approximately $90 \%$ were from Poland; over three quarters were aged between 18 and 34 years; around two thirds were male and were employed in factory work. The demographics of A8 migrants in Crewe thus generally reflected the national picture (see Stenning et al, 2006; Pollard et al, 2008; Burrell, 2009). These local figures are nevertheless still claimed to underestimate the true scale of Polish migration with anecdotal accounts suggesting the number was in fact much higher. Regardless of the exact numbers, local accounts emphasised the 'felt' change in the area with many different accents and different appearances in a town that had very little diversity previously. 


\section{The Methodological Approach}

Minorities' and migrants' experiences and perceptions are vastly underexplored in contemporary quantitative criminological research due, in the most part, to the immense challenge and expense of doing so (see Phillips and Bowling, 2003). The present research therefore attempted to fill this void by capturing the perspectives and experiences of both the local established residents (subsequently termed the 'local' group) and the new Polish migrants (subsequently termed the 'migrant' group). In recognition of Phillips and Bowling's (2003: 270) plea to reconcile 'criminological data' and the 'lived experiences' of minorities, a combination of quantitative and qualitative methods and analyses were considered the appropriate research strategy to do this.

\section{The Survey}

To compare the two groups' attitudes, perceptions and experiences, a bilingual survey was designed, translated and administered to 'local' and 'migrant' populations throughout the selected neighbourhoods in Crewe via a 'random walk' sampling design, whereby every $5^{\text {th }}$ household was selected to partake in the survey (see Farrall et al, 1997 for a description). It was originally planned to obtain a random, but not proportionate, equal sample of respondents from the Polish community and from the local community. However, the practice of sampling is not comparable to its theory and it soon became apparent during the research that this would be an unachievable target. While the random sampling method was adhered to for the local population, this method alone was not possible in reality for the migrant population due to the need to oversample this group.

Faugier and Sargeant (1997) stress the need for a mixture of methods to be used when researching 'hidden populations', i.e. those where no sampling frame exists (Birman, 2006) as once random sampling approaches have been saturated, non-random methods often need to be utilised (Dahinden and Efionayi-Mäder, 2009). A targeted sampling approach was therefore adopted which involved the recruitment of migrant respondents at sites identified as salient from 'ethnographic mapping' (Watters and Biernacki, 1989; Heckathorn, 1997: 175). Through using a range of methods and sampling strategies therefore, the researcher was able to include the voices of this 
rather transient and hidden Polish migrant community in the research (see Griffiths, 2014 for further discussion of the sampling strategy and its limitations).

\section{The Sample}

The final sample included a total of 250 respondents: 78 migrant respondents, the 'migrant' group; and 172 local respondents, the 'local' group. Table I below illustrates the composition of the two groups in their socio-demographic characteristics.

\section{[Table I Here]}

As seen in table I, the significant differences between the two groups are in their age, level of education, employment status, length of residence, and household tenure. The migrant group are slightly younger, better educated, more likely to be in paid work, to have lived in the neighbourhood for a much shorter amount of time, and to rent their property, as compared to the local group. The socio-demographic characteristics of the migrant group sample in the current research do therefore appear to closely resemble those of the wider migrant population throughout the UK (see Stenning et al, 2006; Burrell, 2009).

\section{Measures}

\section{Perceptions of immigration as a 'realistic' threat}

Following the social threat hypothesis (McLaren and Johnson, 2007), groups' perceptions of immigration as a 'realistic' threat to resources was measured by asking survey respondents how much they agreed or disagreed with the statements, 'immigration has put pressure on local public services like schools, hospitals and public housing' and 'Polish immigration is good for Crewe's economy'. Respondents could answer on a five-point scale ranging from 'strongly agree' to 'strongly disagree'.

\section{Perceptions of immigration as a 'symbolic' threat}

Secondly, to measure perceptions of immigration as a 'symbolic' threat to the social order of the neighbourhood, respondents were asked the extent to which they agreed or disagreed that 'Polish immigration has changed this neighbourhood for the better', and 'the presence of different groups in this neighbourhood is a good thing'. Again, 
respondents could answer on a five-point scale ranging from 'strongly agree' to 'strongly disagree'.

\section{Perceptions of groups' public behaviour}

Next, to understand how 'locals' and 'migrants' perceive the social conduct and public behaviour of various groups in the neighbourhood, respondents were asked, 'who would you say are the main people who engage in disorderly behaviour and petty crime in your neighbourhood? By disorderly behaviour I mean drinking or being rowdy in public, being noisy, etc.' Responses included 'young people', 'men', 'British people', 'women', 'Polish people', 'students', and 'outsiders'. This was a multiple response item, whereby respondents could tick as many options as they wished. This item therefore captures perceptions of 'uncivil' behaviour in line with Elias and Scotson (1965).

\section{Community relations and group conflict}

The final step is to assess how group perceptions translate into community relations. Four items were incorporated in the questionnaire to capture both positive and negative community interaction. Firstly, to measure group tension, respondents were asked how much they agreed or disagreed with the statements, 'sometimes I feel tension with neighbours that are not [British/Polish'1]' and 'there are ethnic groups living in this neighbourhood that I do not think positively of'. Secondly, to measure perceptions of community cohesion, respondents were asked the extent to which they agreed or disagreed that 'this is a close-knit neighbourhood' and 'people in this neighbourhood generally get on well with each other'. Respondents could answer on a five-point scale ranging from 1 (strongly agree) to 5 (strongly disagree).

\section{Supplementing the Survey: Qualitative Methods}

As a supplement to the quantitative component of the study, additional qualitative methods were incorporated to provide a more in-depth and interpretive account. Two focus groups were additionally carried out, one with members of the 'local' community and one with members of the 'migrant' community. Interviews with experts and key representatives from local institutions and organisations were conducted to gain the institutional perspective, including interviews with the local police, the local Borough

\footnotetext{
1 'British' in local group questionnaire, 'Polish' in migrant group questionnaire.
} 
council, and local landlords. Finally, field observations were recorded in a field diary from such sources as local newspapers, Neighbourhood Action Meetings (NAMs) organised by the local Borough Council, and conversations with people in their neighbourhoods. The qualitative data will be incorporated throughout the findings section to add greater depth and understanding to the quantitative data.

\section{Findings}

Immigration as a 'Realistic' Threat

Table II displays the differences between local and migrant respondents' attitudes toward immigration as a 'realistic' threat. As seen, locals' and migrants' perceptions differ most markedly when asked whether 'Polish immigration is good for Crewe's economy'.

\section{[Table II Here]}

As table II shows, $50.9 \%$ of the local group consider that Polish migration has had a negative impact on Crewe's economy, demonstrated through disagreement with this statement. In contrast, $82.1 \%$ of the migrant group believe that Polish migration has had a positive effect on the local economy, demonstrated through agreement with this statement. This difference between the two groups is highly significant. A migrant survey respondent who has lived in Crewe for over 18 years provides an account of how the more recent Polish migration has benefited the area:

"I think that England benefited from Polish immigration in my town, in Crewe. In a very fast pace empty houses are renovated for Polish families. Also, a few new neighbourhoods were built and new trade is emerging. The town is growing" [Migrant Survey Respondent].

This respondent, who is part of the more established Polish migrant generation living in Crewe, believes that the recent influx of young Polish workers and families has revitalised the town, bringing with it increased trade, redevelopment of properties, and 
increased neighbourhood organisation. However, perhaps unsurprisingly, local residents do not agree with this perspective.

Table II further demonstrates that $76.2 \%$ of the local group express a concern over the increased demand on local resources resulting from migration, stating that they either agree or strongly agree with the statement, 'immigration has put pressure on local public services like schools, hospitals and public housing'. A local focus group participant captures some of this concern:

"I think that the main problem is ... that we've had a very large increase in population ... over a period of probably up to five years, less than five years ... they don't all necessarily speak English and with the children they put extra demands on schools, they put extra demands on doctors on the health facilities in the town, and I think to have such a large increase over such a short period of time puts a great strain on the normal structure of everyday living" [Keith, Local Focus Group].

Local residents are thus overwhelmingly in agreement that recent migration has placed extra demands on the town. However, $65.3 \%$ of the migrant group similarly agree on the resource strain such migration can induce, and no significant difference between the two groups is found (see table II).

These findings provide supporting evidence of immigration as a perceived 'realistic threat' to limited economic and social resources by the established population (Blalock, 1967, cited Herreros and Criado, 2009; King and Wheelock, 2007; Meuleman et al, 2009). Nevertheless, while some would argue this constitutes a form of 'subtle' (Meuleman et al, 2009: 353) or 'popular' (Kundnani, 2001: 43) prejudice against immigrants, the current findings are less supportive of this view, as new migrants agree that their presence threatens and places extra pressure on access to social and welfare services.

\section{Immigration as a 'Symbolic' Threat}

Focusing more specifically on how locals and migrants perceive migration to have impacted 'symbolically' upon the social order of their neighbourhoods, table III shows 
that nearly two thirds of the local group perceive that Polish migration has changed their neighbourhood for the worse (63.4\%), compared to a third of the migrant group (35.1\%). However, table III also shows that the migrant group responses are evenly distributed across the response categories, with a third of the migrant group stating immigration has changed their neighbourhood for the better, and a further third expressing no opinion. While local residents are thus in strong agreement that immigration is a 'symbolic' threat to their neighbourhood social order, the migrant group hold more heterogeneous attitudes and appear to find it more difficult to assess the impacts of immigration for neighbourhood social order as compared to assessments of the economy, for example.

\section{[Table III here]}

Next, when asked whether 'the presence of different groups in this neighbourhood is a good thing', $66.2 \%$ of the migrant group perceive that living in a heterogeneous neighbourhood with a variety of other groups living there is a positive consequence of immigration compared to just $40.1 \%$ of the local group. Again this difference is significant (see table III).

As McLaren and Johnson (2007: 13-14) recognise, the threat posed by immigration for local residents can be "... symbolic in nature and may stem from concerns about the loss

of certain values or a way of life because of the presence of minority groups and immigrants." Established local residents in Crewe therefore typically view the recent Polish migration as both a 'realistic' threat to economic and social resources, as well as a 'symbolic' threat to the 'veneer of civility' (Innes, 2004: 341) and hence the social order of the neighbourhood. So far, the current findings are in line with the gloomy tale told in the current academic literature of immigration and its perceived consequences for social order.

\section{Perceptions of Groups' Public Behaviour}

Taking this a step further, the paper now turns its attention away from exploring perceptions of immigration more generally to assess how groups perceive each other. Focusing firstly on the local group, those most commonly perceived by local residents as 
'disorderly' in their neighbourhood (with a third of total responses) are young people (see figure I).

\section{[Figure I Here]}

Of all the groups considered as sources of disorder, figure I shows the subsequent highest share of responses are for men (16.6\%) and British people (12.5\%). The local group rank their Polish neighbours as the fifth most likely group to behave in a disorderly manner in the neighbourhood, with only $10.3 \%$ of responses. Therefore, it could be suggested that local residents generally perceive acts of disorder in their neighbourhood to mostly be committed by those within the community boundaries young people, men, British people and women. Groups beyond their own community Polish people, students and outsiders - are considered less problematic and disorderly in their neighbourhood. This finding echoes those presented by Girling et al (2000), whereby in a community in 'middle England', the everyday mundane crime talk typically centred on the perceived uncivil behaviour of local youth within the community.

Crucially, although earlier findings illustrate that local residents hold negative perceptions of migration as a 'realistic' and 'symbolic' threat to the neighbourhood, the current findings suggest these local residents do not attribute the everyday sources of disorder in their neighbourhood to migrants themselves. This asserts that locals do not necessarily hold prejudicial attitudes toward their migrant neighbours, but do associate the general process of migration, as a mass influx of individuals, as having negative social order impacts. This is a subtle yet important differentiation between perceptions of migration and perceptions of migrants as sources of disorder. Kumlin's (2004) conceptualisation of 'sociotropic' and 'egotropic' attitudes can be applied here, whereby a distinction exists between negative 'sociotropic' attitudes regarding migration as a general social process, and more positive 'egotropic' attitudes regarding migrants as neighbours (see also Griffiths, 2013 for a further discussion of this distinction in attitudes). 
There is indeed a possibility that the local group had already settled on a different targeted 'other' that was not included in the responses to this question. There is no opportunity for respondents to give a racist response here for example. However, there is very little evidence of hate crime as a particular problem in Crewe with the official police statistics showing low levels recorded throughout the area. Local police accounts confirm this:

"I mean one of our roles here is to monitor the number of race hate type incidents ... I would've expected it to be a hot-bed of race hate crime and quite honestly it isn't and I think the statistics prove that" [Crewe Police Sergeant 2].

While there are of course problems with hate crime data, this fits with the wider picture that has emerged in Crewe with no strong or convincing evidence of generalised intercommunity conflict.

Next, when the migrant group were asked which group of people they felt were the most likely to engage in disorderly behaviour and petty crime, the most common response, again, is young people (31.8\%; see figure II).

\section{[Figure II Here]}

Figure II shows that the subsequent highest share of responses for the migrant group is for British people as sources of disorder (23.7\%), closely followed by Polish people (18.7\%). Men (16.2\%), women (7.1\%), students $(1.5 \%)$ and outsiders $(1.0 \%)$ are considered disorderly to a less extent. For the current purposes, the most interesting aspect of these findings is the difference between groups in their perceptions of British people and Polish people as sources of disorder. The proportion of the migrant group who perceive both British and Polish people as sources of disorder is nearly double that of the local group.

This finding counters existing research. It demonstrates that rather than the local 'established' population holding negative out-group attitudes toward the 'encroaching group' (Skogan, 1990: 44), it is the 'encroaching group' themselves who hold slightly 
more negative assumptions regarding the social misconduct of both the out-group (British people) and the in-group (Polish people). One explanation for this comes from Lenski's (1954) idea of 'status inconsistency'. According to Zhou (2005), new migrants are typically considered middle class and highly educated before migrating to their new country. Upon arrival in the new place of residence, however, these migrants are initially more likely to receive a low income (Zhou, 2005). The changing status or 'status inconsistency' (Lenski, 1954) of migrants with a high education but current low income can thus be said to result in a greater intolerance towards the social misconduct of their new neighbours. Despite this, although Polish migrants seem to express more negative attitudes toward both Polish migrants and established residents in Crewe, the percentage who do so still remains relatively low.

\section{Community Relations and Group Conflict}

The final task is to consider how these perceptions translate into inter-community relations. Table IV below displays the results.

\section{[Table IV Here]}

Firstly, a small but significant difference between the local and migrant groups' experiences of tension within the neighbourhood is found $(p<.05)$. As shown in table IV, $28.8 \%$ of the local group either 'agree' or 'strongly agree' that they sometimes experience tension with their non-British neighbours, compared to a total of $14.6 \%$ of the migrant group who state that they sometimes experience tension with their nonPolish neighbours. This finding suggests that the local group experience significantly more inter-group tension than the migrant group, although it is ultimately still a rather small percentage of the local group who report such tension as the small difference shows. It is also not clear with whom this tension exists. Nevertheless, over half of the local group and nearly three quarters of the migrant group in fact state that they do not experience tension with members of the out-group.

Secondly, no significant difference between the two groups is found for the item 'there are ethnic groups in this neighbourhood that I do not think positively of'. Here, in total, 
only $18.6 \%$ of the migrant group and $23.5 \%$ of the local group express negative outgroup attitudes by stating that they either agree or strongly agree with this statement. Similarly, no significant difference is found between the groups on either of the final two items measuring perceptions of community cohesion. Nearly half of both the local group (45.3\%) and the migrant group (44.9\%) do not perceive their neighbourhood to be a close-knit place to live but despite this, over three quarters of each group either agree or strongly agree that people generally get along well with each other in their neighbourhood ( $82.5 \%$ of the local group and $75.6 \%$ of the migrant group). These findings therefore suggest that norm coherence exists between the local and migrant groups in Crewe, where groups perceive their neighbours and neighbourhood in a similar light - not as a close-knit place to live, but where groups do get along well with each other.

For example, comments from Polish migrants during a focus group demonstrate civil experiences of social exchange with local residents:

Dorota: I have once left my keys in the door, which were very visible as I had a small teddy bear attached to it. After a while I heard a knocking at my door. I was looking for the keys to open the door, however, at first I was reluctant to open it because there were many youths outside the door. When I finally grabbed the handle, the door was open and one of the youths handed the keys over to me. I was taken aback that I didn't even say anything. I was expecting something different. This happened to me twice.

Wojciech: I remember a situation in my previous neighbourhood, where we had a lawn which wasn't fenced off, when two boys came knocking at our door...

Olga: (interrupting Wojciech) ... I opened the door and one of the boys was saying something to me, which I couldn't understand. Finally, the boy pointed at the ball on our lawn and I realised that he wanted his ball back. I was amazed that the boys didn't simply take the ball themselves but instead they asked my permission. 
This discussion is just one of many examples provided by migrants during a focus group of civil and courteous experiences with local residents in Crewe. Many migrants express how polite and pleasant they find local people, with small gestures and minor courtesies having a positive impact on migrants' experiences in Crewe. Other examples of these small but important gestures include helping with car problems, the giving of car parts, being addressed in a polite way, waving, saying hello or simply smiling to each other in the street:

Wojciech: Even though I don't meet my neighbours very often, things like holding the door or patiently waiting for a parking space are common and nice to experience.

Szymon: English people are generally more approachable and open than Poles. Even strangers greet each other on the streets.

These minor courtesies of everyday life amongst 'strangers on the streets' may be taken for granted amongst local residents as the norm in their neighbourhood, but for new Polish migrants in Crewe they mean so much more and allow for positive and civilised relationships to exist between groups rather than conflict and animosity.

Furthermore, the local group provide various examples of civility and courtesy with Polish migrants. The first example comes from an elderly local woman who, in an informal conversation with the researcher during the survey fieldwork, described an incident of civility with one of her Polish neighbours. This local resident was walking to the supermarket one day when it began to rain heavily. A Polish woman hurried across and escorted her with an umbrella to the supermarket. The Polish woman did not speak any English but the two women have since met on the street in their neighbourhood and have smiled and said 'hello' to each other. A second example comes from a local resident during a focus group discussion:

'I was doing something on my van and the battery had gone flat so I was gonna charge it and was taking it off and it snaps and I thought "oh my goodness what am I am going to do here?" And the Polish neighbour, I mentioned it to him and he took 
it off, got in the car, went off, came back, had a piece for me, put it on, there you go. The Polish neighbours are quite startlingly different to what I expected, they've been very very helpful and friendly' [Nigel, Local Focus Group].

These accounts demonstrate how although there are language barriers, friendly communication and minor courtesies do transcend cultural boundaries in Crewe. What is interesting about this latter story and the ones offered by Dorota and Olga from the migrant focus group is that the positive episodes experienced between the local residents and the new migrants were unexpected. In all accounts, participants report feeling surprised by the others' actions. According to the focus group accounts, these 'small manifestations of civility' (Wuthnow, 2002: 218) have the potential for dissipating any prior negative assumptions of the expected out-group behaviour.

\section{Discussion}

\section{Civilised Communities: Towards a New Modus Vivendi?}

"...human nature seems, on the whole, to prefer the sight of kindness and friendliness to the sight of cruelty. Normal men everywhere reject, in principle and by preference, the path of war and destruction. They like to live in peace and friendship with their neighbors; they prefer to love and be loved rather than hate and be hated"

(Allport, 1958: x).

This paper provides one of the few in-depth empirical case studies that explored how both 'established' residents and new migrants perceive, adapt and negotiate their social relationships with each other after a period of mass migration. Rather than supporting the traditional 'gloomy tale' told regarding immigration, diversity and community relations, the current paper instead tells a more nuanced and subtle story. Although intangible, or 'sociotropic', perceptions of immigration as a general social process were found to be associated with a perceived disruption to neighbourhood social order amongst established residents in Crewe, tangible or 'egotropic' experiences of migrants as neighbours were not. There is an argument looming in much academic and vernacular discourse as to whether negative attitudes and concerns regarding immigration and its impacts constitute an 'implicit' (Sampson, 2009: 20), 'sophisticated' 
(Bobo, 1983: 1201), or 'popular' (Kundnani, 2001: 43) form of racism or prejudice. The present findings highlight an interesting paradox in the public opinions of immigration however. While the majority of the 'local' group express concerns regarding migration as a mass social movement of people and its 'realistic' and 'symbolic' consequences for Crewe, they express tolerant, and in some instances even favourable, views toward the orderly behaviour of migrants as neighbours living alongside them.

Through small norms of courtesy and politeness, the social order in the studied locale was managed and maintained through weak but 'civilised relationships' between migrants and established residents, thus failing to culminate into conflict between the two groups. In contrast to Elias and Scotson's (1965: 153) notion of 'civilising differentials' that sustain hostile boundaries between social groups, local and migrant groups in Crewe instead strive to find the 'civilising equivalences' that exist between them. In the current research therefore, 'othering' is related to sociotropic migration, but not to egotropic experiences of it. What exists instead is an effort to find common ground or shared social norms between established and newcomer groups; that is, rather than adopting a process of 'othering', local residents and new migrants in Crewe engage in an 'equivalising' process. Crucially, such 'small manifestations of civility' (Wuthnow, 2002: 218) were able to counter any prior negative assumptions. This can help explain the discrepancy between negative sociotropic, but positive egotropic, attitudes. It also shows the importance of encouraging contact between diverse groups and how living in diverse areas has the potential to result in 'passive tolerance' (Christ et al, 2014).

As the quote from Allport (1958) at the beginning of this section similarly highlights, there is evidence that in general people act in positive 'other-regarding' ways, and that they engage in self-sacrificing behaviours that benefit others more so than they act in a purely rational self-interested fashion (Sampson, 2012: 214). Sampson interestingly suggests that such a culture of altruism and 'other-regarding' norms are likely to exist in immigrant neighbourhoods, thus countering Putnam's (2007) dystopian claims in his 'hunkering down' thesis. Others have also countered the 'gloomy tale': "even in the bleak and unforgiving landscape of prison, a convivial imagination is actively fostered by prisoners and refuses to be extinguished by the enormous morbid and melancholic 
force of imprisonment" (Earle and Phillips, 2009: 136). However, Phillips (2008: 320321) did find that racism had a 'hidden presence' which did not surface in day to day relations but could during times of conflict. It is very difficult to know for sure if this 'civility' amongst groups in Crewe was a false exterior or one that ran deep to the core of individuals' values and beliefs. Either way, such "ordinary, spontaneous anti-racism, that generate the little triumphs that bring real pleasure ... that foster the small arts and crafts of living-with-others" (Gilroy, 2004 cited in Earle and Phillips, 2009: 135-136) still have value in making life viable in diverse communities.

While there is a growing body of literature that supports the findings here, it is important to note that this is a single case study that cannot make claims to generalisability. Nevertheless, understanding the distinctiveness of 'place' has important implications for the social relations that exist within it. As Girling et al (2000: 11) note,

"if we wish to understand the filtration of generic social representations of crime [or indeed immigration] ... into everyday sensibility we will also need to comprehend the situated character of their reception and appropriation by people in the practical and mundane contexts of their daily life."

It is therefore entirely possible that the findings of 'civility' here are determined by the specific migration and social context in which the research took place. Why was it then that the 'gloomy tale' did not generally exist between these groups in Crewe unlike other areas nearby? Gadd and Dixon (2011) found in Stoke-on-Trent for example that immigration was entangled with wider concerns around unemployment, crime, and inadequate housing and health care provision whereby the white working class considered themselves to be the "losers' or cultural and economic failures" (Gadd and Dixon, 2011: 21). Concerns over realistic and symbolic threats of immigration were indeed found to result in race hate crime based on the 'unacknowledged shame' that can be experienced amongst the marginalised and deprived established communities where new immigrants settle (Ray et al, 2004). This relates to the idea of 'status insecurity'. Such feelings of powerlessness and political abandonment did on the one hand help explain feelings of racism and prejudice amongst the established residents in Stoke-on- 
Trent that allowed a blame to be targeted on 'foreigners', 'immigrants' and 'strangers'. On the other hand though, Gadd and Dixon (2011) showed how it also allowed these same individuals to, in some cases, 'identify with the other'. Those who had experienced some warmth or generosity "from those they might otherwise have regarded as outsiders" were generally left feeling uncomfortable about engaging in prejudiced generalisations (Gadd and Dixon, 2011: 230). As Phillips (2008: 325) therefore suggests, it is perhaps 'class' that should remain central here in understanding the nuances of such social relationships, whereby class-based solidarity or identification is more important than ethnic identification.

Therefore, Gadd and Dixon (2011: 21) argue for the importance of 'identifying with the other'. This is difficult with demonised others that are unknown or unknowable, but does again show the importance of contact and striving for some common sentiment. Perhaps with the Polish migrant community in Crewe, establishing some common sentiment was easier to do. As shown earlier, Crewe's distinctiveness lies in its strong identity as an industrial and railway town. Crewe's history of a strong work ethic thus may play a part in shaping contemporary 'civilised relationships' that manifest amongst diverse social groups in the current research. Perhaps the established community in Crewe were less 'status insecure' than those in other areas, such as Stoke-on-Trent for example. Furthermore, this contemporary migration is argued to be a 'new' type than that upon which previous research is based, resulting in an alternative public discourse (Stenning et al, 2006; The Economist, 2008; Burrell, 2009). The lack of a 'racial' element and the further 'invisibility' of Polish migrants based on religion and social values; the demographics of migrants as young, without dependents, highly educated, and with strong aspirations to work; and the long established history of Polish migrants in the UK following WWII (Stenning et al, 2006; The Economist, 2008; Pollard et al, 2008; Burrell, 2009), may help to explain why 'civilised relationships' exist in Crewe rather than a process of 'othering'. Other migrant communities may not share such a strong normative consensus with the established community, thus civilised relationships and a lack of inter-group conflict may be less achievable in situations of 'shock' migration in other forms. In other neighbourhoods, with different historical contexts and with different social groups, immigration may be experienced and perceived in a differential way. Nevertheless, there remain important lessons to be learned here. For example, it 
remains important to allow for diversity and alternative voices to speak out in plural communities, while at the same time celebrating common ground and stressing the shared, rather than diverse, social values groups possess. Emphasising and promoting mutuality, collective sentiment and commonality is therefore crucial rather than focusing on difference (Young, 2003). This paper has also shown the importance of localism and how the complex wider historical and social context helps us to understand groups' differential responses to migration and how everyday mundane civility between strangers can be the result. 
Allport, G.W. (1958) The Nature of Prejudice. USA: Addison-Wesley.

Bauman, Z. (1997) Postmodernity and Its Discontents. Cambridge: Cambridge Polity Press.

Birman, D. (2006) 'Ethical Issues in Research with Immigrants and Refugees', in Trimble, J.E., and Fisher, C.B. (Eds.) The Handbook of Ethical Research with Ethnocultural Populations and Communities. Thousand Oaks: Sage.

Bobo, L. (1983) 'Whites' Opposition to Busing: Symbolic Racism or Realistic Group Conflict?' Journal of Personality and Social Psychology, 45(6): 1196-1210.

Bottoms, A. (2009) 'Disorder, Order and Control Signals', British Journal of Sociology, 60(1): 49-55.

Bunting, M. (2014) 'If you don't think multiculturalism is working, look at your street corner', The Guardian, 16th March 2014.

Burgess, E.W. (1925) 'The Growth of the City: An Introduction to a Research Project', in Park, R.E., Burgess, E.W., and McKenzie, R.D. (Eds.) The City. Chicago and London: University of Chicago Press.

Burrell, K. (2009) Polish Migration to the UK in the 'New' European Union: After 2004. Surrey: Ashgate Publishing.

Campbell, D. (2012) 'Has Eastern European Immigration Fuelled a Crime Wave in Britain?' The Guardian, 25th June 2012.

Christ, O., Schmid, K., Bolliot, S., Swart, H., Stolle, D., Tausch, N., Al Ramiah, A., Wagner, U., Vertovec, S., and Hewstone, M. (2014) 'Contextual effect of positive intergroup contact on outgroup prejudice', PNAS, 111(11): 3996-4000. 
Christiansen, R. (1993) Rail Centres: Crewe. Nottingham: Booklaw Publications.

Dahinden, J., and Efionayi-Mäder, D. (2009) 'Challenges and Strategies in Empirical Fieldwork with Asylum Seekers and Migrant Sex Workers', in Van Liempt, I., and Bilger, V. (Eds.) The Ethics of Migration Research Methodology: Dealing with Vulnerable Immigrants. Sussex Academic Press.

Drummond, D.K. (1995) Crewe: Railway Town, Company and People 1840 - 1914. Aldershot: Scolar Press.

Earle, R., and Phillips, C. (2009) 'Con-viviality and Beyond: Identity Dynamics in a Young Men's Prison', in Wetherell, M. (Eds.) Identity in the 21st Century: New trends in Changing Times. Hampshire: Palgrave Macmillian.

Elias, N., and Scotson, J.L. (1965) The Established and The Outsiders: A Sociological Enquiry into Community Problems. London: Frank Cass.

Farrall, S., Jackson, J., and Gray, E. (2009) Social Order and the Fear of Crime in Contemporary Times. Oxford: Oxford University Press.

Farrall, S., Bannister, J., Ditton, J., and Gilchrist, E. (1997) 'Questioning the Measurement of the 'Fear of Crime': Findings from a Major Methodological Study', British Journal of Criminology, 37(4): 658-679.

Faugier, J., and Sargeant, M. (1997) 'Sampling Hard to Reach Populations', Journal of Advanced Nursing, 26: 790-7997.

Gadd, D., Dixon, B., and Jefferson, T. (2005) 'Why Do they Do It? Racial Harassment in North Staffordshire', Keele University: Staffordshire. Retrieved From: http://www.keele.ac.uk/depts/cr/Gadd/whydotheydoitfinal.pdf.

Girling, E., Loader, I., and Sparks, R. (2000) Crime and Social Change in Middle England: Questions of Order in an English Town. London: Routledge. 
Griffiths, C.E. (2013) 'Living with Aliens' Criminal Justice Matters, 93(1): 26-27.

Griffiths, C.E. (2014) 'Researching "Hidden Populations": Reflections of a Quantitative Researcher in Understanding "Established" and "Immigrant" Groups' Perceptions of Crime and Social (Dis)Order', in Lumsden, K., and Winter, A. (Eds.) Reflexivity in Criminological Research: Experiences with the Powerful and the Powerless. Basingstoke: Palgrave Macmillan.

Heckathorn, D.D. (1997) 'Respondent-Driven Sampling: A New Approach to the Study of Hidden Populations', Social Problems, 44(2): 174-199.

Herreros, F., and Criado, H. (2009) 'Social Trust, Social Capital and Perceptions of Immigration', Political Studies, 57: 337-355.

Home Office, Department for Work and Pensions, HM Revenue and Customs, and the Department for Communities and Local Government (2006) 'Accession Monitoring Report: May 2004 - June 2006', Retrieved From:

https://webmail.keele.ac.uk/src/download.php?startMessage=31\&passed $\mathrm{id}=1 \& \mathrm{~m}$ ailbox $=$ Research + Contacts\&ent $\mathrm{id}=2 \&$ passed ent $\mathrm{id}=0$

Hughes, G. (2007) 'Community Cohesion, Asylum Seeking and the Question of the 'Stranger", Cultural Studies, 21(6): 931-951.

Innes, M. (2004) 'Signal Crimes and Signal Disorders: Notes on Deviance as Communicative Action', The British Journal of Sociology, 55(3): 335-355.

King, R.D., and Wheelock, D. (2007) 'Group Threat and Social Control: Race, Perceptions of Minorities and the Desire to Punish', Social Forces, 85(3): 1255-1280.

Kumlin, S. (2004) The Personal and the Political: How Welfare State Experiences Affect Political Trust and Ideology. New York: Palgrave. 
Kundnani, A. (2001) 'In a Foreign Land: The New Popular Racism', Race and Class, 43(2): 41-60.

Lenski, G.E. (1954) 'Status Crystallization: A Non-Vertical Dimension of Social Status', American Sociological Review, 19(4): 405-413.

McKenzie, R.D. ([1924] 1971) 'The Ecological Approach to the Study of the Human Community', in Short, J.F. (1971) The Social Fabric of the Metropolis. Chicago: University of Chicago Press.

McLaren, L., and Johnson, M. (2007) 'Resources, Group Conflict and Symbols: Explaining Anti-Immigration Hostility in Britain', Political Studies, 55(4): 709-732.

Meuleman, B., Davidov, E., and Billet, J. (2009) 'Changing Attitudes toward Immigration in Europe, 2002-2007: A Dynamic Group Conflict Theory Approach', Social Science Research, 38: 352-365.

North, C.C. ([1926] 1971) 'The City as a Community: An Introduction to a Research Project', in Short, J.F. (1971) The Social Fabric of the Metropolis. Chicago: University of Chicago Press.

Office for National Statistics, Home Office, and the Department for Work and Pensions (2011) 'Migration Statistics Quarterly Report - User Information', Retrieved From: http://www.ons.gov.uk/ons/taxonomy/search/index.html?pageSize=50\&sortBy=n one\&sortDirection=none\&newquery=Migration+Statistics+Quarterly+Report++User+Information\%E2\%80\%99\&contenttype=publicationContentTypes\&nscl=International+Migration

Park, R.E., Burgess, E.W., and McKenzie, R.D. (1925) The City. Chicago: University of Chicago Press.

Phillips, C. (2008) 'Negotiating Identities: Ethnicity and Social Relations in a Young Offenders' Institution', Theoretical Criminology, 12(3): 313-331. 
Phillips, C., and Bowling, B. (2003) 'Racism, Ethnicity and Criminology: Developing Minority Perspectives', British Journal of Criminology, 43: 269-290.

Pollard, N., Latorre, M., and Sriskandarajah, D. (2008) Floodgates or Turnstiles? Post-EU Enlargement Migration Flows to (and From) the UK. London: Institute for Public Policy Press.

Putnam, R.D. (2007) 'E Pluribus Unum: Diversity and Community in the Twenty-First Century. The 2006 Johan Skytte Prize Lecture', Scandinavian Political Studies, 30(2): 137-173.

Ray, L., Smith, D., and Wastell, L. (2004) 'Shame, Rage and Racist Violence', British Journal of Criminology, 44(3): 350-368.

Sampson, R.J. (2009) 'Disparity and Diversity in the Contemporary City: Social (Dis)order Revisited', The British Journal of Sociology, 60(1): 1-31.

Sampson, R.J. (2012) Great American City: Chicago and the Enduring Neighborhood Effect. Chicago: The University of Chicago Press.

Simmel, G. ([1908] 1971) 'The Stranger', in Georg Simmel: On Individuality and Social Forms. Edited by Levine, D.N, p. 143-149. Chicago: University of Chicago Press.

Sinclair, J. (2011) 'Britons have "Greater Fear" of Immigration', The Independent, 4th February 2011.

Skogan, W.G. (1990) Disorder and Decline: Crime and the Spiral of Decay in American Neighbourhoods. New York: The Free Press.

Slack, J. (2008) 'Mass Immigration to Blame for Knife Culture, Chief Constable Warns', The Daily Mail, 4th June 2008. 
Stenning, A., Champion, T., Conway, C., Coombes, M., Dawley, S., Dixon, L., Raybould, S., and Richardson, R. (2006) 'Assessing the Local and Regional Impacts of International Migration', Final Report of a Research Project for the Department for Communities and Local Government. Retrieved From: http://www.ncl.ac.uk/curds/publications/pdf/A8Final.pdf

The Economist (2008) 'Immigration Trends: Poles Depart', (30/08/08). The Economist.

Thomas, W.I., and Znaniecki, F. [1918-1920] 1996. The Polish Peasant in Europe and America: A Classic Work in Immigration History. Edited by Eli Zaretsky. Urbana and Chicago: University of Illinois Press.

UK Census (2001) 'Neighbourhood Statistics', Retrieved From: http://neighbourhood.statistics.gov.uk/dissemination/LeadHome.do;jsessionid=ac 1f930cce610b3a5d8ce1f4958bfa6cde45e8890fc.e38Qa3mPbh4Kai0Ma30Sa3uSch mSe6fznA5Pp7ftolbGmkTy?bhcp=1.

Watters, J.K., and Biernacki, P. (1989) 'Targeted Sampling: Options for the Study of Hidden Populations', Social Problems, 36(4): 416 - 430.

Wirth, L. (1938) 'Urbanism as a Way of Life', The American Journal of Sociology, 44(1): 124.

Wuthnow, R. (2002) Loose Connections: Joining Together in America's Fragmented Communities. Cambridge, Massachusetts: Harvard University Press.

Young, J. (1999) The Exclusive Society. London: Sage.

Young, J. (2003) 'To These Wet and Windy Shores: Recent Immigration Policy in the UK', Punishment and Society, 5(4): 449-462.

Zhou, M. (2005) 'Ethnicity as Social Capital: Community-Based Institutions and Embedded Networks of Social Relations', in Loury, G.C., Modoud, T., and Teles, S.M. 
(Eds.) Ethnicity, Social Mobility and Public Policy: Comparing the US and UK. Cambridge: Cambridge University Press. 
Table I: The Socio-Demographics of the 'Local' and 'Migrant' Groups

\begin{tabular}{|c|c|c|}
\hline Item & 'Local' Group & 'Migrant' Group \\
\hline $\operatorname{Age}^{* * *}$ & Mean Age $=48$ years & Mean Age $=36$ years \\
\hline Gender & 61.1\% Female & $52.6 \%$ Female \\
\hline Education $* * *$ & $\begin{array}{c}\text { 16.9\% University/Postgraduate } \\
\text { Degree }\end{array}$ & $\begin{array}{c}\text { 30.2\% University/Postgraduate } \\
\text { Degree }\end{array}$ \\
\hline Income & $44.2 \%$ Earn $<£ 1000$ a month & $36.8 \%$ Earn $<£ 1000$ a month \\
\hline Employment*** & $47.6 \%$ In paid work & $64.1 \%$ In paid work \\
\hline Length of Residence ${ }^{* * *}$ & $58.4 \%>10$ years & $3.8 \%>10$ years \\
\hline Household Tenure ${ }^{* * *}$ & 83.6\% Own Property & 7.7\% Own Property \\
\hline $\mathbf{N}$ & 172 & 78 \\
\hline
\end{tabular}

* Significant at $p<.05 ;{ }^{* *}$ Significant at $p<.01 ;{ }^{* * *}$ Significant at $p<.001$. 
Table II: Locals \& Migrants: Immigration as a 'Realistic' Threat (\% of Responses)

\begin{tabular}{|c|c|c|c|c|}
\hline & \multicolumn{2}{|c|}{$\begin{array}{l}\text { Immigration is good for } \\
\text { Crewe's economy }\end{array}$} & \multicolumn{2}{|c|}{$\begin{array}{c}\text { Immigration has put pressure } \\
\text { on local public services }\end{array}$} \\
\hline & $\begin{array}{l}\text { Local } \\
\%\end{array}$ & $\begin{array}{l}\text { Migrant } \\
\%\end{array}$ & $\begin{array}{l}\text { Local } \\
\%\end{array}$ & $\begin{array}{l}\text { Migrant } \\
\%\end{array}$ \\
\hline $\begin{array}{l}\text { Strongly Agree/ } \\
\text { Agree }\end{array}$ & 24.2 & 82.1 & 76.2 & 65.3 \\
\hline Neutral & 24.8 & 15.4 & 11.3 & 17.3 \\
\hline $\begin{array}{l}\text { Strongly Disagree/ } \\
\text { Disagree }\end{array}$ & 50.9 & 2.6 & 12.5 & 17.3 \\
\hline$N$ & \multicolumn{2}{|c|}{243} & \multicolumn{2}{|c|}{243} \\
\hline Significance & \multicolumn{2}{|c|}{$* * *$} & \multicolumn{2}{|c|}{ NS } \\
\hline
\end{tabular}

NS Non-Significant, $p>.05 ;{ }^{* * *}$ Significant at $p<.001$

Table III: Locals \& Migrants: Immigration as a 'Symbolic' Threat (\% of Responses)

\begin{tabular}{|c|c|c|c|c|}
\hline & \multicolumn{2}{|c|}{$\begin{array}{c}\text { Immigration has changed } \\
\text { neighbourhood for the } \\
\text { better }\end{array}$} & \multicolumn{2}{|c|}{$\begin{array}{c}\text { The presence of different groups } \\
\text { in neighbourhood is a good } \\
\text { thing }\end{array}$} \\
\hline & $\begin{array}{l}\text { Local } \\
\%\end{array}$ & $\begin{array}{l}\text { Migrant } \\
\%\end{array}$ & $\begin{array}{l}\text { Local } \\
\%\end{array}$ & $\begin{array}{l}\text { Migrant } \\
\%\end{array}$ \\
\hline $\begin{array}{l}\text { Strongly Agree/ } \\
\text { Agree }\end{array}$ & 11.0 & 33.8 & 40.1 & 66.2 \\
\hline Neutral & 25.6 & 31.1 & 18.5 & 18.9 \\
\hline $\begin{array}{l}\text { Strongly Disagree/ } \\
\text { Disagree }\end{array}$ & 63.4 & 35.1 & 41.4 & 14.9 \\
\hline$N$ & \multicolumn{2}{|c|}{238} & \multicolumn{2}{|c|}{236} \\
\hline Significance & \multicolumn{2}{|c|}{$* * *$} & \multicolumn{2}{|c|}{$* * *$} \\
\hline
\end{tabular}

NS Non-Significant, $p>.05 ;{ }^{* * *}$ Significant at $p<.001$ 
Table IV: Locals \& Migrants: Community Relations and Group Conflict (\% of Responses)

\begin{tabular}{|c|c|c|c|c|c|c|c|c|}
\hline & \multicolumn{2}{|c|}{$\begin{array}{c}\text { Sometimes I feel } \\
\text { tension with } \\
\text { neighbours that } \\
\text { are not } \\
{[\text { British/Polish }]^{2}}\end{array}$} & \multicolumn{2}{|c|}{$\begin{array}{l}\text { There are ethnic } \\
\text { groups living in this } \\
\text { neighbourhood that } \\
\text { I do not think } \\
\text { positively of }\end{array}$} & \multicolumn{2}{|c|}{$\begin{array}{l}\text { This is a close-knit } \\
\text { neighbourhood }\end{array}$} & \multicolumn{2}{|c|}{$\begin{array}{c}\text { People in this } \\
\text { neighbourhood } \\
\text { generally get on } \\
\text { well with each } \\
\text { other }\end{array}$} \\
\hline & $\begin{array}{c}\text { Local } \\
\%\end{array}$ & $\begin{array}{c}\text { Migrant } \\
\%\end{array}$ & $\begin{array}{c}\text { Local } \\
\%\end{array}$ & $\begin{array}{c}\text { Migrant } \\
\%\end{array}$ & $\begin{array}{l}\text { Local } \\
\%\end{array}$ & $\begin{array}{c}\text { Migrant } \\
\%\end{array}$ & $\begin{array}{c}\text { Local } \\
\%\end{array}$ & $\begin{array}{l}\text { Migrant } \\
\%\end{array}$ \\
\hline $\begin{array}{l}\text { Strongly Agree/ } \\
\text { Agree }\end{array}$ & 28.8 & 14.6 & 23.5 & 18.6 & 37.8 & 25.7 & 82.5 & 75.6 \\
\hline Neutral & 18.4 & 14.7 & 24.7 & 25.3 & 16.9 & 29.5 & 5.2 & 10.3 \\
\hline $\begin{array}{l}\text { Strongly Disagree/ } \\
\text { Disagree }\end{array}$ & 52.7 & 70.6 & 51.9 & 56.0 & 45.3 & 44.9 & 12.3 & 14.1 \\
\hline $\begin{array}{l}\mathrm{N} \\
\text { Significance }\end{array}$ & \multicolumn{2}{|c|}{$\begin{array}{c}238 \\
*\end{array}$} & \multicolumn{2}{|c|}{237} & \multicolumn{2}{|c|}{250} & \multicolumn{2}{|c|}{250} \\
\hline
\end{tabular}

NS Non-Significant, $p>.05 ;{ }^{*}$ Significant at $p<.05$

Figure I: 'Local Group': Groups Perceived as Disorderly (\% of Responses)

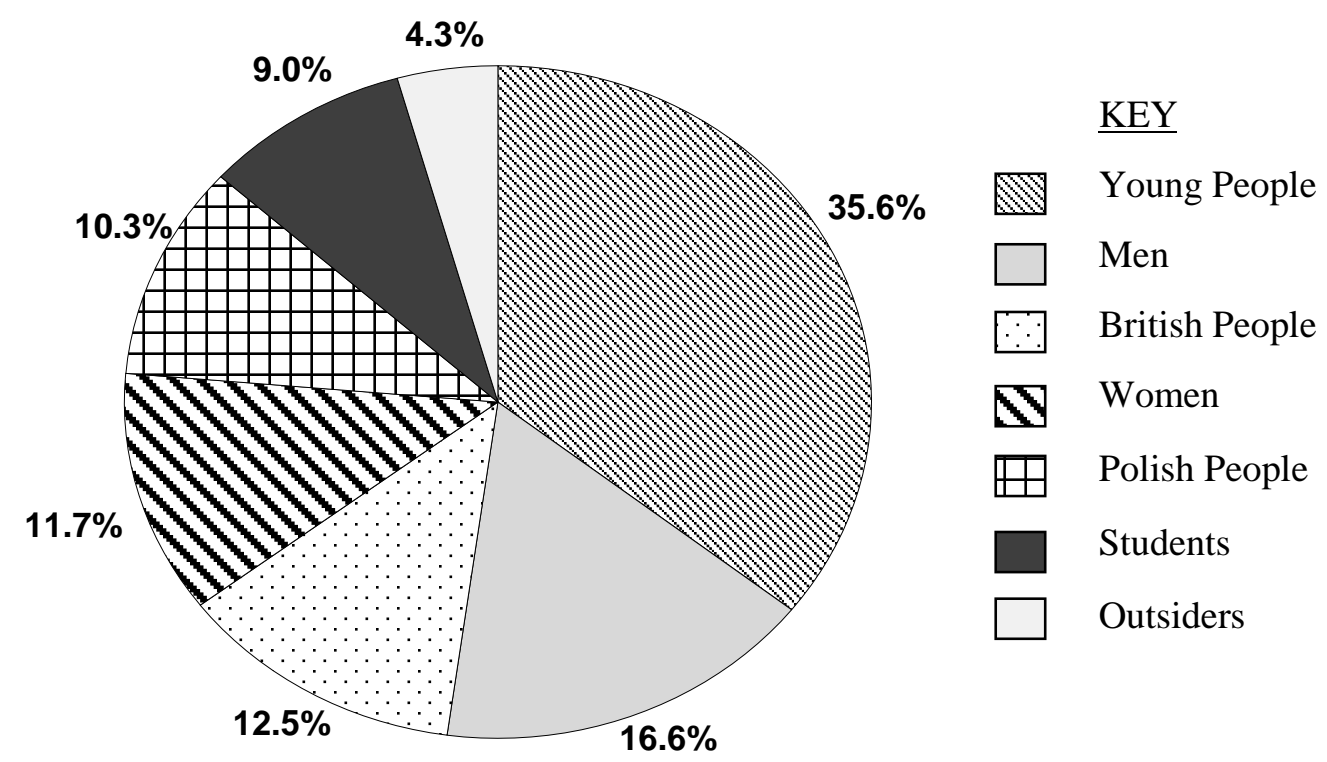

${ }^{2}$ British' in local group questionnaire, 'Polish' in migrant group questionnaire. 
Figure II: 'Migrant Group': Groups Perceived as Disorderly (\% of Responses)

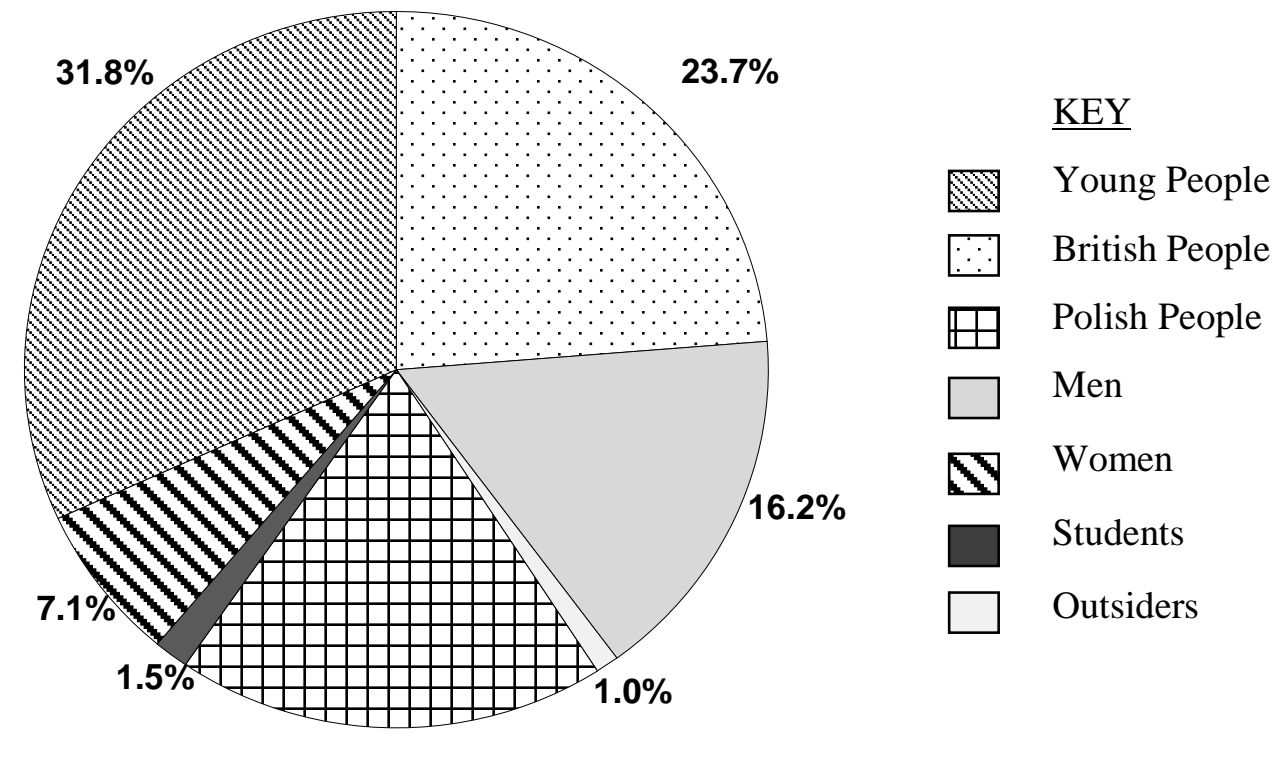

$18.7 \%$ 